\title{
Contributions at Capitalization Study on Chemical Content from Mulberry Tree Leave by Bombyx Mori Larvae
}

\author{
MARIUS GHEORGHE DOLIS ${ }^{1}$, RADU ADRIAN MORARU1*, CRISTINA SIMEANU1*, ION SANDU ${ }^{2,3}$, DAN BODESCU1, \\ VASILE VINTILA* \\ 'University of Agricultural Sciences and Veterinary Medicine of lasi, 3 Mihail Sadoveanu Alley, 700490 lasi, Romania \\ ${ }^{2}$ Alexandru Ioan Cuza University of lasi, Arheoinvest Interdisciplinary Platform, Scientific Investigation Laboratory, 11 Carol I \\ Blvd., 700506 lasi, Romania \\ ${ }^{3}$ Romanian Inventors Forum, 3 Sf. Petru Movila St., Bloc L11, III/3, 700089 Iasi, Romania \\ ${ }^{4}$ Cattle Breeding Research Station from Dancu, lasi - 9 Ungheni Road, 707252 lasi, Romania
}

\begin{abstract}
In order to assess how efficient is the use of mulberryleaf by the Bombyx mori Baneasa Super larvae hybrid, some determinations were made regarding the nutritional value and digestibility of the worm leaf administered as food, during a series of summer growth. The results showed that ongoing vegetation and growth process of this hybrid, the Mulberry leaves suffer an aging phenomenon, revealed by diminishing its chemical composition quality. According to this, most of the nutritional substances from mulberry leaves, except cellulose, manifesta continuous decline during the growth period. The digestibility of these nutritional components registered a value of $56.41 \%$, the crude energy value was $4209 \mathrm{kcal} / \mathrm{kg}$ dry substance, and digestive energy was $2173 \mathrm{kcal} / \mathrm{kg}$ (DS), while the metabolic energy was 2044-2007 kcal/kg (DS). The efficiency of converting ingestion into silk had a value of $9.30 \%$ and the digestion was $15.76 \%$.
\end{abstract}

Keywords: leaves, mulberry, larvae, energy, use

Besides the continuous improvement of the growth technologies, one of the main concerns of the specialists in sericulture is represented by the production of biological material of high genetic value as the Bombyx mori larvae with an increasing productive potential, more resistant to the environmental factors and to diseases and to use nutrients offered by the mulberry to the best of their advantage [ 1 - 5].

Thus, from this point of view, the performances of the used larvae in intensive breeding systems have greatly increased, but at the same time, in order for them to be able to reach their full potential, it is necessary to improve all the factors involved in the breeding process. From the multitude of factors that directly influence the growth process of the larvae and the economic results obtained, it is encountered also nutrition $[4,5]$.

The quantity and especially the quality of the worm leaf used in feeding of larvae, directly influence the growth rate, their health and vitality, but also the quantitative and qualitative production of silk. In turn, the quality of the leaf is also influenced by many factors related to the pedoclimatic conditions, season, variety of the mulberry, the way of harvesting and storage etc. [1 - 3].

The knowledge of nutritive value and influence factors, as well as the way in which Bombyx mori larvae capitalize the nutritive substances from mulberry leaf, were included in many scientific research. So, some studies, targeted, from this point of view, mulberry species [ 1 - 7], other studies contribute to the knowledge of digestion particularities at this breed of silkworms [8 - 11] and the way in which it is capitalize the nutritive content of mulberry leaf [12 - 18]. The importance given to nutritive value of mulberry leaf also resulted from the fact that exist studies which aimed to capitalization also at other breeds such as: swines [19, 20], sheep [21 - 24], goats [25, 26], cattle [27], rabbits [28, 29], hens [30, 31], etc.

At the end of the last century, Romania could be considered an important point on the map of European sericulture. Thus, in her record, Romania can boast in this field with a quite complex literature, as well as with the creation of new varieties and valuable hybrids of worm, as Bombyx mori, all being the result of some decade research work of Romanian specialists [32-38].

For this reason, we consider appropriate to bring a modest contribution to the study of using the mulberry leaf, derived from indigenous varieties, by larvae of breeds or hybrids created in Romania.

\section{Experimental part}

The biological material used in the experiments was represented by a batch of 150 larvae of Bombyx morifrom Romanian hybrid Baneasa Super, obtained by a simple cross between the female breed of J apanese type and the male type of Chinese. To be easier to follow, the batch was divided into three sub-batches (repetitions) of 50 larvae each, which were raised in paper trays sized according to the age and size of the larvae; in addition, it was also made up a separate batch, with 50 larvae reared separately, butunder the same conditions, which served to replace the dead larvae from the experimental batch.

The growth of the larvae was in August, in an airconditioned room, in compliance with all the microclimate factors. Each divided batch received the same amount of leaf, from the same variety of worm (Selected hybrid) [2], from where samples were previously collected, for chemical analysis.

Daily and at the same time, from each batch were collected, weighed and recorded what was not consumed from the mulberry leaves and what was excreted by the larvae.

The quantities of residues, respectively of excrements, obtained from each batch were summed, the result being divided into three, thus obtaining the average quantity of residues from each 50 larvae. The values obtained were subsequently used in the calculation relationships to find the digestibility coefficients. Also, from each batch were collected samples of excrements, which were mixed in

* email: ramoraru@yahoo.com; cristina.simeanu@yahoo.com; vasilevintilais@yahoo.com

REV.CHIM.(Bucharest) 70 No. $10 \diamond 2019 \quad$ http://www.revistadechimie.ro 
order to obtain medium samples for analyze. Also, the batches were weighed at the beginning of growth (after hatching) and at the end (before budding), the difference betw een the two weights, divided by the number of larvae in each batch, representing the increase in body mass accumulated by a larva.

From the separated batch were extracted 10 larvae, whose content was determined in dry matter; thus, multiplying the average dry substance content of larvae, calculated from the separated batches, with the increasing body mass of the larvae in the experimental batches, it was determined the average increasing of body mass of a larva.

After gobbling, 15 cocoons were harvested, from which the silk wrapper was separated, weighed and its dry matter content determined, thus obtaining the average dry wool content of the silk wrapper.

The working methods used were mainly the specific ones used to determine the nutritional value of the worm leaf and they were based on the chemical composition (the proximate analysis scheme), the digestibility of its components (the in vivo method - simple digestibility, with a single control period) and crude energy (use of specific computation equations and regression coefficients recommended by the OKIT system), digestible (calculation equation recommended for monogastric species) and metabolizable (equations recommended for monogastric animals and birds) contained [39-58].

The efficiency of the use of nutrients in the worm leaf by the larvae was expressed by the amount of ingested/ digested dry matter required for increasing 1 gram of body mass/weight (silk wrap), respectively by the efficiency of conversion of ingested substances (ECl\%)/digested (ECD\%) in body mass/weight $[6,13,18]$.

\section{Results and discussions}

Table 1 shows the data of the chemical composition evolution of larvae in relation to their age. According to data obtained it can be observed that during the course of the experience the values of relative humidity of the worm leaf had a downward evolution, recording on average values betw een $71.96 \%$, in the period corresponding to the age of the larvae and $68.24 \%$, during the period when the larvae were in age V. During the studied period, the worm leaf had on average $29.38 \pm 0.676 \%$ dry matter respectively $70.62 \%$, water.

The humidity directly influences the leaf consumption by the larvae, which especially in the early ages, prefers it with a high percentage of water.

In the specific literature, depending on differentfactors, the relative humidity values of the mulberry leaf vary between $65-75 \%$ [32].
Compared with the common mulberry (69.80-73\%), the selected varieties have more water content [59]. The dried substance from the worm leaf, harvested in the same period, can record, depending on the variety/hybrid, different values, for example, betw een $23.61 \%$ and $27.56 \%$ [6].

Also, if the spring moisture of the mulberry leaf is 71.85$77.81 \%$, then it decreases to $68.42-75.64 \%$, in the summer period, respectively to $64.10-73.64 \%$, in the fall [60].

The crude protein from the mulberry leaf, compared to the dry substance, had values between $21.86 \%$ at first age, $18.99 \%$ at fifth age and during the whole studied period an average of $20.78 \pm 0.627 \%$. At the end of growth, crude protein content of the leaf registered a reduction of 2.86 percentage points.

The protein content of the worm leaf strongly influences the growth and development of silk larvae and especially their silk production. In the specific literature, the crude leaf protein is estimated to have an average value of $6.16 \%$ in the fresh leaf, $20.97 \%$ in the dry substance and $24.36 \%$ in its organic substance [32]. The crude leaf protein values can vary depending on the season, the time of day, the variety/hybrid of the dude: $32.40 \%$ in spring, $28.21 \%$ in summer and $24.53 \%$ in autumn [ 61 ], $26.80 \%$ in the morning and $29,10 \%$ in the evening [62], between $22.55 \%$ and $25.73 \%$ depending on the variety [6].

The crude fat of the worm leaf registered an average value of $3.70 \pm 0.294 \%$ and during the period of growth of the larvae registered an increase from $2.96 \%$ (in the period of age I) to $4.47 \%$ (in the period of the age V), the data obtained being comparable to those presented by the specialized literature: 2.85-6.07\% [63] and 3.4-6.0\% [59].

The crude cellulose, related to the dry substance, had an average value of $18.10 \pm 0.271 \%$, which registered an increase of $1.47 \%$ during the growth period of the larvae, from 17.55 to $19.02 \%$.

Increased cellulose content causes aging of the worm leaf, which becomes harder and harsher, therefore harder to consume by, which is why those varieties whose leaves have less cellulose content are considered more valuable.

According to the data from the specialized literature, in the common mulberry the weight of the crude cellulose ranges between $12.33-14.38 \%$, while in the different varieties selected oscillates between $10.43-13.70 \%$ [64]. In the vegetation period of the mulberry the content in crude cellulose from the leaves increases from 14.47 to $21.16 \%$ [63].

The unaccounted extractive substances, compared to dry substance, had an average weight of $43.22 \pm 0.183 \%$, during the period of growth of the larvae first recording a decrease, from the first determination to the third, respectively from 43.61 to $42.90 \%$, followed by an increase until the fourth determination, reaching $43.69 \%$, then

\begin{tabular}{|c|c|c|c|c|c|c|c|c|c|c|c|c|}
\hline \multirow{2}{*}{ Determination } & \multirow{2}{*}{ Water } & \multirow{2}{*}{ DM } & \multicolumn{2}{|r|}{$\mathrm{CP}$} & \multicolumn{2}{|r|}{$\mathrm{EE}$} & \multicolumn{2}{|c|}{ CF } & \multicolumn{2}{|c|}{ NFE } & \multicolumn{2}{|c|}{ Ash } \\
\hline & & & $F^{8}$ & $\mathrm{DM}^{* *}$ & $F^{8}$ & $\mathrm{DM}^{* *}$ & $F^{8}$ & $\mathrm{DM}^{* *}$ & $\mathrm{~F}^{8}$ & $\mathrm{DM}^{* *}$ & $\mathrm{~F}^{8}$ & $\mathrm{DM}^{* *}$ \\
\hline I & 71.96 & 28.04 & 6.13 & 21.86 & 0.83 & 2.96 & 4.92 & 17.55 & 12.23 & 43.61 & 3.93 & 14.02 \\
\hline II & 71.75 & 28.25 & 6.23 & 22.05 & 0.87 & 3.08 & 4.99 & 17.66 & 12.18 & 43.12 & 3.98 & 14.09 \\
\hline III & 71.03 & 28.97 & 6.21 & 21.44 & 1.12 & 3.87 & 5.18 & 17.88 & 12.43 & 42.90 & 4.03 & 13.91 \\
\hline IV & 70.13 & 29.87 & 5.85 & 19.58 & 1.23 & 4.12 & 5.49 & 18.38 & 13.05 & 43.69 & 4.25 & 14.23 \\
\hline V & 68.24 & 31.76 & 6.03 & 18.99 & 1.42 & 4.47 & 6.04 & 19.02 & 13.59 & 42.79 & 4.68 & 14.73 \\
\hline$\overline{\mathrm{x}}$ & 70.62 & 29.38 & 6.09 & 20.78 & 1.09 & 3.70 & 5.32 & 18.10 & 12.71 & 43.22 & 4.17 & 14.20 \\
\hline$s_{x}$ & - & 0.676 & - & 0.627 & - & 0.294 & - & 0.271 & - & 0.183 & - & 0.143 \\
\hline $\mathrm{V} \%$ & - & 5.147 & - & 6.744 & - & 17.775 & - & 3.349 & - & 0.947 & - & 2.256 \\
\hline Min. & - & 28.04 & - & 18.99 & - & 2.96 & - & 17.55 & - & 42.79 & - & 13.91 \\
\hline Max. & - & 31.76 & - & 22.05 & - & 4.47 & - & 19.02 & - & 43.69 & - & 14.73 \\
\hline
\end{tabular}

Table 1

CHEMICAL COMPOSITION OF MULBERRY LEAF

IN RELATION TO LARVAE'S AGE (\%) 
another decrease until the last determination (until $42.79 \%)$.

The crude ash accounted an average value of $14.20 \pm 0.114 \%$ on dry matter in the leaf. During the study period, the mineral substances in the leaf of the worm generally registered a progressive increase (by $0.71 \%$ ) from the first determination to the fifth, respectively from $14.02 \%$ to $14.73 \%$, except for the third determination, where there was a lower value even than the first determination.

The values regarding the mineral substances, obtained from the calcinations of the mulberry leaf, are comparable to those offered by the specialized literature: $9.13-17.38 \%$ [63], $11.52-12.80 \%$ [6] and $8.7-13.15 \%$ [59].

Knowing the crude chemical composition of the mulberry leaf, using the specific calculation equations, it was possible to assess the nutritional value of the mulberry leaf based on its content of crude energy, which was, on average, over the entire studied period, of $1237 \mathrm{Kcal} / \mathrm{kg}$, in fresh leaf, respectively $4209 \mathrm{Kcal} / \mathrm{kg}$, in the dry matter (Table 2).

By recording the quantities of the worm leaf administered, the non-consumed and excreted residues and also determining their chemical composition (Table 3), its digestibility coefficients could subsequently be calculated (Table 4) and also the content of digestible substances in the leaf (Table 5).
Following the complex phenomenon of digestion, nutrients are transformed into simple substances, which can thus be absorbed through the epithelium of the digestive tract, at different levels, thus being retained in the organism of silk larvae, representing practically the difference between the amount of substances ingested through food and the amount of appropriate substances found in droppings. Because not all the substances found in excrement are of dietary origin, some of them are of endogenous origin, which can be obtained by this difference, indicating only apparent digestibility. If you admit the fact that at Bombyx mori excretions are also found in their excrement, which complicates the establishment of the digestibility of nutrients in the wormwood even more accurately, the use of the approximate digestibility term seems to be more correct $[8,14,17,65,66]$.

During the whole period studied, the digestibility of the dried substance from the worm leaf had a digestibility of $59.04 \%$, the average being $72.67 \pm 5.442 \%$. The highest digestibility was recorded in larvae of age I ( $90.47 \%)$, after which, by the end of the larval period, there was a decrease of 34.06 percent. In the specialty literature, the main explanation for reducing the digestibility of nutrients from the worm leaf as a whole, during the growth period of the silk larvae, would be as seen from the data in Table 1,

\begin{tabular}{|c|c|c|c|c|c|c|c|}
\hline \multirow{2}{*}{ Specification } & \multicolumn{2}{|c|}{$\%$} & \multirow{2}{*}{ Caloric equivalent } & \multicolumn{2}{|c|}{$\mathrm{Kcal} / 100 \mathrm{~g}$} & \multicolumn{2}{|c|}{$\mathrm{Kcal} / 100 \mathrm{~g}$} \\
\hline & * & ** & & $*$ & $* *$ & $*$ & *** \\
\hline $\mathrm{CP}$ & 6.09 & 20.78 & 5.72 & 34.83 & 118.86 & 348.3 & 1188.6 \\
\hline $\mathrm{CF}$ & 1.09 & 3.70 & 9.50 & 10.36 & 35.15 & 103.6 & 351.5 \\
\hline $\mathrm{CC}$ & 5.32 & 18.10 & 4.79 & 25.48 & 86.70 & 254.8 & 867.0 \\
\hline NES & 12.71 & 43.22 & 4.17 & 53.00 & 180.23 & 530.0 & 1802.3 \\
\hline & & & & & & 1237 & 4209 \\
\hline
\end{tabular}

\begin{tabular}{|c|l|c|c|c|c|c|c|c|}
\hline \multirow{2}{*}{ The larvae age } & \multirow{2}{*}{ Specification } & \multirow{2}{*}{ Quantity (g) } & \multicolumn{5}{|c|}{ Chemical composition (\%) } \\
\cline { 3 - 8 } & & & DM & CP & EE & CF & NEF & Ash \\
\hline \multirow{3}{*}{ I } & Leaves & 15.50 & 28.04 & 6.13 & 0.83 & 4.92 & 12.23 & 3.93 \\
\cline { 2 - 8 } & Leftovers & 5.29 & 62.78 & 13.85 & 2.11 & 14.22 & 25.15 & 7.45 \\
\cline { 2 - 8 } & Excreta & 0.14 & 69.81 & 18.42 & 10.15 & 7.36 & 26.99 & 6.89 \\
\hline \multirow{3}{*}{ II } & Leaves & 26 & 28.25 & 6.23 & 0.87 & 4.99 & 12.18 & 3.98 \\
\cline { 2 - 8 } & Leftovers & 8.76 & 59.01 & 13.95 & 2.56 & 14.00 & 24.92 & 3.58 \\
\cline { 2 - 8 } & Excreta & 0.88 & 63.00 & 14.14 & 0.15 & 7.57 & 26.84 & 14.30 \\
\hline \multirow{3}{*}{ III } & Leaves & 77.00 & 28.97 & 6.21 & 1.12 & 5.18 & 12.43 & 4.03 \\
\cline { 2 - 8 } & Leftovers & 23.55 & 59.94 & 12.86 & 1.94 & 16.02 & 24.92 & 4.20 \\
\cline { 2 - 8 } & Excreta & 4.02 & 61.12 & 14.89 & 2.83 & 5.08 & 25.47 & 12.85 \\
\hline \multirow{3}{*}{ IV } & Leaves & 242.00 & 29.87 & 5.85 & 1.23 & 5.49 & 13.05 & 4.25 \\
\cline { 2 - 8 } & Leftovers & 66.02 & 56.21 & 12.09 & 2.66 & 17.03 & 21.05 & 3.38 \\
\cline { 2 - 8 } & Excreta & 18.98 & 60.85 & 9.77 & 2.34 & 9.22 & 25.18 & 14.34 \\
\hline \multirow{3}{*}{ V } & Leaves & 1000 & 31.76 & 6.03 & 1.42 & 6.04 & 13.59 & 4.68 \\
\cline { 2 - 8 } & Leftovers & 267.00 & 56.10 & 10.21 & 1.88 & 14.30 & 25.01 & 4.7 \\
\cline { 2 - 8 } & Excreta & 121.00 & 60.45 & 10.00 & 4.05 & 14.95 & 24.33 & 7.12 \\
\hline
\end{tabular}

\begin{tabular}{|c|c|c|c|c|c|}
\hline The larvae age & DM & CP & EE & CF & NEF \\
\hline I & 90.47 & 88.14 & 16.96 & 0.96 & 92.99 \\
\hline II & 74.52 & 68.73 & 31.58 & 6.20 & 75.99 \\
\hline III & 70.00 & 65.86 & 71.94 & 5.42 & 72.34 \\
\hline IV & 71.95 & 69.97 & 63.61 & 14.32 & 72.97 \\
\hline V & 56.41 & 63.38 & 46.62 & 18.59 & 57.41 \\
\hline I-V & 59.04 & 64.64 & 49.57 & 18.07 & 61.42 \\
\hline $\bar{x}$ & 72.67 & 71.22 & 46.14 & 9.10 & 74.34 \\
\hline $\mathrm{s}_{\mathbf{x}}$ & 5.442 & 4.383 & 10.086 & 3.206 & 5.670 \\
\hline V\% & 16.745 & 13.762 & 48.887 & 78.786 & 17.056 \\
\hline Min. & 56.41 & 63.38 & 16.96 & 0.96 & 57.41 \\
\hline Max. & 90.47 & 88.14 & 71.94 & 18.59 & 92.99 \\
\hline
\end{tabular}


precisely the qualitative degradation of the leaf, in terms of chemical composition [18]. Digestibility of the dry substance from the worm leaf decreases from $71.07 \%$ in age I, to $39.99 \%$ (for male larvae), $48.26 \%$ (for female larvae) in age V [66]. The worm leaf administered to the larvae of the fifth age has an approximate digestibility between 27.99 and $32.44 \%$ [ 13$]$.

The crude protein had a digestibility coefficient for the entire studied period of $64.64 \%$, with an average of $71.22 \pm 4.383 \%$. The crude protein digestibility decreased progressively during the studied period, with $24.76 \%$, respectively from $88.14 \%$, in the first larval age, to $63.38 \%$, in the last one.

The high digestibility of age I could be explained by the rich content in amides, simple nitrogenous substances, which are found in the young leaf and which are digested much easier than the protein nitrogenous substances, which have the weight in the old leaf.

In the specialty literature, for crude leaf protein, the value of digestibility coefficients is between $69.21 \%$ and 78.92 [67], $60.06 \%$ and $74.69 \%$ [68], $71.62 \%$ and $93.48 \%$ [6].

The crude fat from the worm leaf had the minimum digestibility value of $16.96 \%$, in the larvae of the first age and maximum of $71.94 \%$, in the larvae of the third age.

The results of the digestibility tests regarding the crude fat in the worm leaf are generally inconclusive, as many of these can come from the intestine of the larvae and not from the leaf, which is why, we cannot speak of a determination of the digestibility of the fat itself but of the ethereal extract, which also contains very large quantities of pigments. Thus, the big differences regarding the evolution of the digestibility of the crude fat during the studied period could be explained.

In the literature, the values of the digestibility coefficient for crude fat are between $63.28 \%$ and $74.19 \%$ [68] .

During the whole larval period, the digestibility of the crude cellulose from the mulberry leaf was $18.07 \%$ the average value was $9.10 \pm 3.206 \%$, being very low in age I, $0.96 \%$, after which it increased progressively, by over $17 \%$, reaching the end of the period studied up to the value of
$18.07 \%$. This increase in the digestibility of crude cellulose, as the larvae grow older, is in line with the development of the enzymatic equipment in their digestive tract. Thus, if at age I, in the digestive tract of the larvae, the enzymes involved in the process of cellulose digestion are as nonexistent, then they gradually increase, reaching the peak at age $V$, at which point the weight of crude cellulose from the worm leaf it is also bigger. This aspect, however, negatively influences the digestibility of the crude leaf protein, which during the same period, is experiencing a reduction.

At the beginning of the last century, some authors found that the leaf cellulose passes undigested through the digestive tract of the larvae and later it was concluded that this substance has a digestibility of approx. 20\% [1-3, 32]. Recently, some authors state that in the first two ages, crude cellulose would not be digested, but only from the third ( $8 \%$ ), its digestibility reaches $21.13 \%$ in the third period [6].

Unclaimed extractive substances from the worm leaf had a digestibility over the entire studied period of $61.42 \%$, with an average of $74.34 \pm 5.670 \%$, the digestibility coefficients registering decreasing values, from $92.99 \%$, in the case of the larvae of age I, at $57.41 \%$, in the case of those of fifth age.

According to Matei [6], for the extracts not recorded from the leaf of the worm, the digestibility coefficients for the whole larval period record average values between $63.40 \%$ and $94.97 \%$.

From the data in table 3 it can be observed that the digestibility of the nutrients of the worm leaf showed a medium variability for dry matter, crude protein and high for crude fat and crude cellulose.

Knowing the value of digestibility coefficients, it was possible to calculate the digestible content for each nutrient separately, then the content of digestible substances in the leaf, so when the report was made to the fresh leaf, $139 \mathrm{~g}$ of Total Digestive Substance/kg were obtained, and when the report was made on the dried substance from the leaf of the mulberry, its nutritional value was $474 \mathrm{~g}$ TDS/kg (Table 5).

\begin{tabular}{|c|c|c|c|c|c|c|c|}
\hline \multirow[t]{2}{*}{ Specification } & \multicolumn{2}{|c|}{ Crude chemical composition $\%$} & \multirow{2}{*}{$\begin{array}{l}\text { Digestibility } \\
\text { coefficients }\end{array}$} & \multicolumn{2}{|c|}{ Digestive content $\%$} & \multicolumn{2}{|c|}{$\begin{array}{l}\text { G Total Digestive } \\
\text { substance } / \mathrm{kg}\end{array}$} \\
\hline & 8 & 88 & & 8 & $7 *$ & & \\
\hline $\mathrm{CP}$ & 6.09 & 20.78 & 64.64 & 3.94 & 13.43 & 39.40 & 134.30 \\
\hline $\mathrm{CF}$ & 1.09 & 3.70 & 49.57 & 0.54 & 1.83 & 12.15 & 41.18 \\
\hline $\mathrm{CC}$ & 5.32 & 18.10 & 18.07 & 0.96 & 3.27 & 9.60 & 32.70 \\
\hline NES & 12.71 & 43.22 & 61.42 & 7.81 & 26.55 & 78.10 & 265.50 \\
\hline Total & & & & & & 139 & 474 \\
\hline
\end{tabular}

Table 5

CRUDE AVERAGE ENERGY OF MULBERRY LEAF

\begin{tabular}{|c|c|c|c|c|c|}
\hline \multirow[b]{2}{*}{ Specification } & \multicolumn{2}{|c|}{ Digestive content $\%$} & \multirow{2}{*}{$\begin{array}{c}\text { Caloric equivalent } \\
(\mathrm{Kcal} / \mathrm{g})\end{array}$} & \multicolumn{2}{|c|}{$\mathrm{Kcal} / 100 \mathrm{~g}$} \\
\hline & & 88 & & $*$ & $* *$ \\
\hline $\mathrm{CP}$ & 3.94 & 13.43 & 5.78 & 227.73 & 776.25 \\
\hline $\mathrm{CF}$ & 0.54 & 1.83 & 9.42 & 50.87 & 172.39 \\
\hline $\mathrm{CC}$ & 0.96 & 3.27 & 4.40 & 42.24 & 143.88 \\
\hline NES & 7.81 & 26.55 & 4.07 & 317.87 & 1080.59 \\
\hline & & & & 639 & 2173 \\
\hline
\end{tabular}

Table 6

DIGESTIVE ENERGY OF MULBERRY LEAF

\begin{tabular}{|c|c|c|c|c|c|c|c|c|c|c|}
\hline \multirow{3}{*}{ Specification } & \multicolumn{2}{|c|}{ Digestive content \% } & \multirow{2}{*}{\multicolumn{2}{|c|}{ Caloric equivalent $(\mathrm{Kcal} / \mathrm{g})$}} & \multicolumn{6}{|c|}{$\mathrm{Kcal} / 100 \mathrm{~g}$} \\
\hline & \multirow{2}{*}{8} & \multirow{2}{*}{88} & & & & & & & & \\
\hline & & & swine & birds & swine & birds & swine & birds & swine & birds \\
\hline $\mathrm{CP}$ & 3.94 & 13.43 & 5.01 & 4.26 & 197.39 & 167.84 & 684.93 & 572.12 & 3.94 & 13.43 \\
\hline$\overline{C F}$ & 0.54 & 1.83 & 8.93 & 9.50 & 48.22 & 51.30 & 163.42 & 173.85 & 0.54 & 1.83 \\
\hline $\mathrm{CC}$ & 0.96 & 3.27 & 3.44 & 4.23 & 33.02 & 40.61 & 112.49 & 138.32 & 0.96 & 3.27 \\
\hline \multirow[t]{2}{*}{ NES } & 7.81 & 26.55 & 4.08 & 4.23 & 318.65 & 330.36 & 1083.24 & 1123.07 & 7.81 & 26.55 \\
\hline & & & & & & & 597 & 590 & 2044 & 2007 \\
\hline
\end{tabular}

Table 7

METABOLIC ENERGY OF MULBERRY LEAF 
Table 8

EFFICIENCY OF USING MULBERRY LEAF BY BOMBIX MORI BANEASA SUPER LARVAE HYBRID

\begin{tabular}{|l|l|l|}
\hline $\begin{array}{l}\text { Average body mass gained during } \\
\text { the whole larvae stage (g) }\end{array}$ & Living larvae & 5.0985 \\
\cline { 3 - 3 } & Dry matter & 0.9254 \\
\hline Silky shell mass (g dry matter) & 0.3989 \\
\hline Dry matter of ingested leaf (g) & 4.2876 \\
\hline Dry matter of digested leaf (g) & 2.5316 \\
\hline Ingested dry matter/body mass dry matter (g) & 4.6332 \\
\hline Dry matter ingested/body mass dry matter (g) & 2.7357 \\
\hline Dry matter ingested/silky shell dry matter (g) & 10.7486 \\
\hline Dry matter digested/sillky shell dry matter (g) & 6.3465 \\
\hline CEI body mass (\%) & 21.58 \\
\hline CED body mass (\%) & 36.55 \\
\hline CEI silky shell (\%) & 9.30 \\
\hline CED silky shell (\%) & 15.76 \\
\hline
\end{tabular}

The determination of the digestible energy content of the worm leaf administered in the feed of silk larvae was made based on the relative digestible content of the nutrients contained in it, using the calorific equivalents recommended for monogastric animal species (Table 6). In the case of the fresh leaf, the digestible energy content was $639 \mathrm{Kcal} / \mathrm{kg}$, and in the case of the dry substance, $2173 \mathrm{Kcal} / \mathrm{kg}$.

The calculation of the metabolic energy from the worm leaf administered in the feed of silk larvae was done by multiplying the digestible content of each nutrient with the energy equivalents recommended for monogastric (pig) animal species. Considering, however, the specificity of the silkworm's digestion, respectively the similarity with the digestion of the birds, for the estimation of the metabolic energy from the worm leaf, the energetic equivalents recommended for the birds were used (Table 7).

The average content in metabolic energy from the fresh mulberry leaf was $597 \mathrm{Kcal} / \mathrm{kg}$, when the recommended energy ratios for pigs were used, respectively $590 \mathrm{Kcal} / \mathrm{kg}$, when the recommended coefficients for birds were used. In relation to the dry matter of the leaf, the content in metabolic energy was on average $2044 \mathrm{Kcal} / \mathrm{kg}$, when the recommended energy coefficients for pigs were used, and $2007 \mathrm{Kcal} / \mathrm{kg}$, when the recommended coefficients for birds were used.

In order to determine the efficiency of use of the nutrients in worm leaf by the silk larvae, except for the intake and digestion, which were calculated during the course of the digestibility tests, it was necessary to determine the average growth rate of the larvae and the mass of the silk shell. The data necessary for calculating the efficiency of the use of the worm leaf by the larvae, as well as the results obtained in this respect, were centralized in Table 8. From the data of this table it is observed that in the case of the Bombyx mori Baneasa Super larvae hybrid, for every gram of silk wrap is required 10.75 grams of dry matter ingested from the wormwood, respectively 6.35 grams of digested dry matter, resulting in an efficiency of conversion of silk intake (CEI) of $9.30 \%$, respectively of digestion (CED) of $15.76 \%$.

The data obtained from the experience performed, regarding the efficiency of the use of the mulberry leaf by the larvae of Bombyx mori, are comparable with those presented in the literature $[6,13,18,65,66]$.

\section{Conclusions}

From this paper the following conclusions are drown: related to drymatter from the mulberry leaves, the average

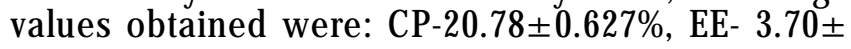

$0.294 \%$, CF - $18.10 \pm 0.271 \%$, NEF - $43.22 \pm 0.183 \%$ and ash$14.20 \pm 0143 \%$. Regarding vegetation advancement and implicitly during each growth period of silkworm larvae, the mulberry leaf ages and its quality from the chemical composition point of view is decreasing. During the 30 days of the research, was noticed a decreasing of the moisture with $3.72 \%$ and of the $C P$ with $0.1 \%$ and in the same time an increasing of the CF with $1.12 \%$.

The leaves nutrients digestibility was in average $72.67 \pm 5.442 \%$. The dry matter digestibility decreased with $34.06 \%$. Digestibility coefficients of the CP (71.22 $\pm 4.383 \%)$ and of the NFE (74.34 $\pm 5.670 \%)$ from the mulberry leaves decreased during the study with $24.76 \%$ and $35.58 \%$, respectively. The CF digestibility which is very low at the beginning, increased progressively till the fifth larval stage when it was $18.59 \%$.

Nutritional value of the mulberry leaves was $474 \mathrm{~g}$ TDN/ $\mathrm{kgDM}$. Throughoutthe studied period, the gross enrichment of the worm leaf was on average $1237 \mathrm{Kcal} / \mathrm{kg}$, in the fresh leaf, respectively $4209 \mathrm{Kcal} / \mathrm{kg}$, in the dry substance. In the case of fresh leaf, the content of digestible energy was $639 \mathrm{Kcal} / \mathrm{kg}$, and in the case of dry matter, $2173 \mathrm{Kcal} / \mathrm{kg}$. In relation to the dry matter of the leaf, the content in metabolic energy was on average $2044 \mathrm{Kcal} / \mathrm{kg}$, when the recommended energy coefficients for pigs were used, and $2007 \mathrm{Kcal} / \mathrm{kg}$, when the recommended coefficients for birds were used. In relation to the dry matter of the leaf, the content in metabolic energy was on average $2044 \mathrm{Kcal} /$ $\mathrm{kg}$, when the recommended energy coefficients for pigs were used, and $2007 \mathrm{Kcal} / \mathrm{kg}$, when the recommended coefficients for birds were used.

In the case of the Baneasa Super hybrid, for each gram of silk wrap, 10.75 grams of dry matter ingested from the mulberry tree are required, respectively 6.35 grams of digested dry substance, resulting an efficiency of conversion of ingestion (CEI) into silk of $9.30 \%$, respectively of the digestion (CED) of $15.76 \%$.

\section{References}

1.DOLIS, M.G., SIMEANU, C., USTUROI, A., SIMEANU, D., Rev. Chim. (Bucharest), 68, no. 1, 2017, p. 151.

2.DOLIS, M.G., BOISTEANU, P.C., SIMEANU, D., Rev. Chim. (Bucharest), 68, no. 6, 2017, p. 1459.

3.DOLIS, M.G., BOISTEANU, P.C., USTUROI, M.G., SIMEANU, D., BODESCU, D., NACU, G., USTUROI, A., SIMEANU, C., Rev. Chim. (Bucharest), 69, no. 2, 2018, p. 439.

4.HIRANO, S., YOSHIDA, S., TAKABUCHI, N., Carbohydrate Polymers, 22, no. 2, 1993, p. 137

5.NEGI, P.S., SUBRAMANI, S.P., International J ournal of Conservation Science, 6, no. 4, 2015, p. 657

6.MATEI, A., Determination of the nutritional value of the main varieties and hybrids of mulberry used in the industrial growth of Bombyx mori, PhD Thesis, University of Agriculture Science and Veterinary Medicine Bucharest, 1995.

7.MENEGUIM, A.M., LUSTRI, C., de OLIVEIRA, D.D., YADA, I.F.U., PASINI, A., Neotropical Entomology, 39, no. 4, 2010, p. 506.

8.MIRANDA, J.E., TAKAHASHI, R., Sericologia, 38, no. 4, 1998, p. 601. 9.0KAMOTO, F, RODELLA, R.A., Pesquisa Agropecuaria Brasileira, 41, no. 2, 2006, p. 195.

10.PASCA, I., MARGHITAS, L.A., MORAR, R., CIMPEAN, A., PUSTA, D., Animal Husbandry and Biotechnologies Book, Series: Buletinul Universitatii de Stiinte Agricole si Medicina Veterinaria Cluj-napoca, Medicina Veterinara Series, 62, 2006, p. 153.

11.PAUL, D.C., RAO, G.S., DEB, D.C., Journal of Insect Physiology, 38, no. 3, 1992, p. 229.

12.PATRUICA, S., Agricultura Banatului, XVII, no. 3, 2008, p. 23. 13.RAHMATHULLA, V.K., SURESH, H.M., MATHUR, V.B., GEETHA, DEVI, R.G., Sericologia, 42, no. 2, 2002, p. 197. 
14.RAHMATHULLA, V.K., MATHUR, V.B., GEETHA, DEVI, R.G., Philippine Journal of Science, 133, no. 1, 2004, p. 39.

15.RAHMATHULLA, V.K., NAYAK, P., VINDYA, G.S., HIMANTHARAJ , M.T., RAJAN, R.K., Animal Biology, 56, no. 1, 2006, p. 13.

16.RAHMATHULLA, V.K., DAS, P., RAMESH, M., Tropical Zoology, 24, no. 2, 2011, p. 145.

17.SABHAT, A., MALIK, M.A., MALIK, F.A., SOFI A.M., MIR, M.R., African J ournal of Agricultural Research, 6, no. 1, 2011, p. 120.

18.SARKAR, A., Sericologia, 33, no. 1, 1993, p. 25.

19.LETERME, P., BOTERO, M., LONDONO, A.M., BINDELLE, J., BULDGEN, A., Animal Science, 82, Part: 2, 2006, p. 175.

20.LEE, S.I., KIM J.K., HANCOCK, J.D., KIM, I.H., J ournal of Applied Animal Research, 45, no. 1, 2016, p. 209.

21.TODARO, M., SINACORI, A., MARINARO, G., ALICATA, M.L. GIACCONE, P., J ournal of Animal and Veterinary Advances, 6, no. 4, 2007, p. 509.

22.GANAl, A.M., AHMAD, H.A., BILAL, S., Animal Nutrition and Feed Technology, 10, no. 1, 2010, p.133.

23.YULISTIANI, D., JELAN, Z.A., LIANG, J.B., YAAKUB, H., ABDULLAH, N., Asian-Australasian J ournal of Animal Sciences, 28, no. 4, 2015, p. 494.

24.CIRNE, L.G.A., SOBRINHO, A.G.D., SANTANA, V.T., SILVA, F.U., de OLIVEIRA, E.A., de ALMEIDA, F.A., ENDO, V., TAKAHASHI, R., de CARVALHO, G.G.P., ZEOLA, N.M.B.L., Semina-Ciencias Agrarias, 35, no. 3, 2014, p. 1523

25.OMAR, S.S., SHAYO, C.M., UDEN, P., Tropical Grasslands, 33, no. 3, 1999, p.177.

26.AZIM, A., KHAN, A.G., AHMAD, J., AYAZ, M., MIRZA, I.H., AsianAustralasian J ournal of Animal Sciences, 15, no. 1, 2002, p. 34.

27.KABI, F., BAREEBA, E., Animal Feed Science and Technology, 140, no. 1-2, 2008, p. 178.

28.27 BHATT, R.S., MONDAL, D., SHARMA, R.B., RISAM, K.S., Anima Nutrition and Feed Technology, 8, no. 2, 2008, p. 289.

29.CANUL-KU, L.A., LARA-LARA, P.E., AGUILAR-URQUIZO, E., ORTIZORTIZ, J.R., MAGANA-MAGANA, M.A., SANGINES-GARCIA, J .R., Revista Cientifica-Facultad de Ciencias Veterinarias, 23, no. 2, 2013, p. 126. 30.OLTEANU, M., PANAITE, T., CIURESCU, G., CRISTE, R.D., Indian J ournal of Animal Sciences, 82, no. 8, 2012, p. 914.

31.AL-KIRSHI, R.A., ALIMON, A., ZULKIFLI, I., ATEFEH, S., WAN ZAHARI, M., IVAN, M., Italian J ournal of Animal Science, 12, no. 2, 2013, p. 219. 32.DOLIS, M., Sericultura. Ed. Alfa, Iasi, 2008, p. 116.

33.DINITA, G., Lucrari stiintifice, Seria Zootehnie, 45, Ed. Ion Ionescu de la Brad lasi, 2002, p. 831.

34.DINITA, G., IANITCHI, D, TUDORACHE, M., CUSTURA, I., VLAD, I., Lucrari stiintifice Acta Universitatis Cibiniensis, Seria Stiinte Agricole, I, no. 1(3), Ed. Universitatii Lucian Blaga Sibiu, 2003, p. 138.

35.DINITA, G., DEZMIREAN, D.S., The 36rd International Session of Scientific Communications of the Faculty of Animal Science Bucharest, Ed. Granada, 2007, p. 23.

36.DINITA, G., MATEI, A., DEZMIREAN, D.S., International Conference Sericulture Challenges in the 21st Century (Serishal 2007) \& the 3rd BACSA meeting, Vratza, Bulgaria, 2007, p. 19.

37.DINITA, G., DEZMIREAN, D., NICOLAE, C.G., ANTONESCU, C., PURDOIU, S., Scientific Papers, Animal Science, Series D, LI, Ed. Coral Sanivet, Bucharest, 2008, p. 50.

38.DINITA, G., J ournal of Biotechnology, 161 S, Kayseri/Turkey, 2012, p. 22.
39.SIMEANU, D., Nutritia si alimentatia animalelor, Ed. Ion Ionescu de la Brad lasi, 2018, p. 44.

40.***, REGULATION (EC) no. 152/2009 SR ISO 6496:2001.

41.***, REGULATION (EC) no. 152/2009 SR EN ISO 2171:2001.

42.***, REGULATION (EC) no. 152/2009 SR EN ISO 5983-2:2009 AOAC 2001.11 .

43.***, REGULATION (EC) no. 152/2009 SR ISO 6492:2001.

44.***, REGULATION (EC) no. 152/2009 SR EN ISO 6865:2002.

45.DINITA, G., TUDORACHE, M., MATEI, A., ANTONESCU, C., MARMANDIU, A., Lucrari stiintifice, Seria Zootehnie, 47, Ed. Ion Ionescu de la Brad, lasi, 2004, p. 684.

46.CRISTE, F.L, MIERLITA, D., SIMEANU, D., BOISTEANU, P.C., POP, I.M., GEORGESCU, G., NACU G., Rev. Chim. (Bucharest), 69, no. 9, 2018, p. 2454.

47.FRUNZA, G., SIMEANU, D., POP, C., LAZAR, R., BOISTEANU, P.C., STEFAN, M., Rev. Chim. (Bucharest), 70, no. 1, 2019, p. 174.

48.FRUNZA, G., SIMEANU, D., POP, I.M., BOISTEANU, P.C., STEFAN, M., Rev. Chim. (Bucharest), 70, no. 2, 2019, p. 512.

49.AVARVAREI, B.V., NISTOR (COTFAS), L.I., SIMEANU, D., MACRI, A.M., Rev. Chim. (Bucharest), 70, no. 3, 2019, p. 759.

50.SIMEANU, D., NISTOR, A.C., AVARVAREI, B.V., BOISTEANU, P.C., Rev. Chim. (Bucharest), 70, no. 4, 2019, p. 1390.

51.RATU, R.N., USTUROI, M.G., SIMEANU, D., SIMEANU, C., USTUROI, A., DOLIS, M.G., Mat. Plast., 54, no. 2, 2017, p. 368.

52.SIMEANU, C., SIMEANU, D., POPA, A., USTUROI, A., BODESCU, D., DOLIS, M.G., Rev. Chim. (Bucharest), 68, no. 5, 2017, p. 1063.

53.LUP, F., POP, I.M., SIMEANU, D., VICAS, S.I., SIMEANU, C., MIERLITA,

D., Rev. Chim. (Bucharest), 69, no. 1, 2018, p. 222.

54.MIERLITA, D., POP, I.M., LUP, F., SIMEANU, D., VICAS, S.I., SIMEANU, C., Rev. Chim. (Bucharest), 69, no. 1, 2018, p. 160.

55.MIERLITA, D., SIMEANU, D., POP, I.M., CRISTE, F., POP, C., SIMEANU C., LUP F., Rev. Chim. (Bucharest), 69, no. 2, 2018, p. 453.

56.NACU, G., BOLOGA, M., POP, C., BOISTEANU, P.C., SIMEANU, D., DOLIS, M.G., DONOSA, R., Rev. Chim. (Bucharest), 69, no. 3, 2018, p. 682.

57.SIMEANU, C., PASARIN, B., BOISTEANU, P.C., SIMEANU, D., DOLIS, M.G., NACU, G., IGNAT, G., HOHA, G.V., Rev. Chim. (Bucharest), 69, no. 10, 2018, p. 2837.

58.USTUROI, A, SIMEANU, C., USTUROI, M.G., DOLIS, M.G., RATU, R.N., SIMEANU, D., Mat. Plast., 54, no. 2, 2017, p. 380.

59.BURA, M., ACATINCAI, S., PADEANU, I., Viermii de matase - biologie si crestere, Ed. Helicon, Timisoara, 1995, p. 27.

60.IFRIM, S., Matasea naturala, Ed. Ceres, Bucharest, 1998, p. 54 61.BORCESCU, A., Sericulture, 3, 1966, p. 6.

62.MARGHITAS, L.A., Cresterea viermilor de matase, Ed. Ceres, Bucharest, 1995, p. 58.

63.POP, E.C., Sericulture, 4, 1967, p. 12.

64.CRAICIU, E., Lucrari stiintifice S.C.A.S. Redactia Revistelor Agricole, Bucuresti, 4, 1966, p. 245.

65.TZENOV, P., Sericologia, 33, no. 2, 1993, p. 247.

66.RATH, S.S., NARAIN, R., PRASAD, B.C., ROY, G.C., SINHA, B.R.R.P., Sericologia, 43, no. 4, 2003, p. 557.

67.BORCESCU, A., Sericulture, 1, 1966, p. 25.

68.PETKOV, N., Sericologia, 20, no. 1-2, 1980, p. 32.

Manuscript received: 16.10 .2019 